\title{
Western science, religion and Vietnamese traditional culture: Harmony or antagonism?
}

\author{
Quang Hung Nguyen - Katarina Valcova - Venera G. Zakirova \\ - Anna A. Larionova - Natalia I. Lapidus
}

DOI: $10.18355 /$ XL.2020.13.03.09

\begin{abstract}
The relationship between religion and science has been very diverse and dynamic in the thousands-year-long history of human thoughts, many times seen as the incompatible terms signifying very opposite realities. In European history, the era of so called or perceived "Dark-Middle-Ages" was dominated by, what is much later defined as the strong antagonism between them. It is true that in the name of religion, some books of ancient Greek and Renaissance philosophers were burned, and some scientists were trialed or even killed. It is therefore necessary to avoid the caricatures and present the more complex view on this matter. The situation in Europe has changed significantly in the 20th century, after the era of the 19th century Rationalism, which has started the process of understanding of the roots of the relationship between science and religion in a new way, offering thus an opportunity of a meaningful dialogue and cooperation rather than antagonism and strict opposition. In Western Europe today, many scientists and theologians are engaged in ongoing and productive dialogue about the relationship of faith and science. In the pre-colonial period, Vietnamese traditional culture was generally Confucian and Buddhist. Then the Confucian traditional education was replaced by the new national education system under the influence of certain Western model. While introducing Marxism, a lot of changes appeared in the relationship between religion and science in the country. Our study describes the relationship between religion and science in Europe and in Vietnam in the past and compares the present-time-situation both, in Europe and in Vietnam.
\end{abstract}

Key words: culture, religion, science, knowledge, truth, values, patterns of behavior

\section{Introduction}

To speak about the relationship between science and religion would not possible without defining the key term naturally creating the framework and context in which science and religion exist - the culture.

\section{Culture}

The present-day-concept of culture has evolved, mostly, throughout the past decades. Merriam-Webster dictionary defines culture as

"the customary beliefs, social forms, and material traits of a racial, religious, or social group; also: the characteristic features of everyday existence (such as diversions or a way of life) shared by people in a place or time; the set of shared attitudes, values, goals, and practices that characterizes an institution or organization; the set of values, conventions, or social practices associated with a particular field, activity, or societal characteristic; the integrated pattern of human knowledge, belief, and behavior that depends upon the capacity for learning and transmitting knowledge to succeeding generations; acquaintance with and taste in fine arts, humanities, and broad aspects of science as distinguished from vocational and technical skills; the act or process of cultivating living material (such as bacteria or viruses) 
in prepared nutrient media." (Merriam-Webster Dictionary, Culture, 2020).

Cambridge Dictionary defines it as "the way of life, especially the general customs and beliefs of a particular group of people at a particular time." (Cambridge Dictionary, Culture, 2020). Both dictionaries offer a broad scope of the meaning of culture portraying the multiple layers of the term connected to activities or concepts to all areas of human existence. Psychological definition of the term "culture" goes more deeply into the layers speaking more precisely about " 1 . The distinctive customs, manners, values, religious behavior, and other social and intellectual aspects of a society. 2. A shared pattern of attitudes, beliefs, self-definitions, role definitions, norms, and values that can be found in a geographic region among those who speak a particular language, or during a particular historic period." (Corsini, 1999: 243). Chaney (2001) also supports the idea of wide meaning and flexibility of the term going hand in hand with necessary changes providing new meanings of the term. He also adds a new twist to the original viewpoint - "structure" or "structural approach" to culture: culture as "a structure of attitudes, values, and normative expectations that lay behind or [are] implicit in the patterns of behavior that [are] characteristics of the community" (Chaney, 2001: 75). He also speaks about flexibility and multi-layers in the meaning of culture, especially when it comes to the present-day mass-media and communication (Chaney, 2001: 76, 78). The result of Chaney's attempt of widevaried-multi-layered-definition of culture speaks about "culture [which]has to be appreciated as a self-conscious repertoire of styles that are constantly being monitored and adapted rather than just forming the unconscious basis of social identity. The approach I seek to make here is to move away from the idea that even within a speech community members speak a common language. Culture is more appropriately imagined as a polyphony of ways of speaking." (Chaney, 2001: 81)

Collier also mentions several types of definitions, prior to main definition: culture as places, as "ancestry and people," as "art and artifact," as "capital or economic resources," as product, as "politics and ideology" (Collier, 2003: 415), as "psychology, worldview, or style of thinking and speaking," as performance, and as group identity (Collier, 2003: 416). Finally, she offers her own definition leading the understanding of the culture within the area of society and politics: "Currently, I define culture as a historically based, interpretive, constitutive, creative set of practices and interpretive frames that demonstrate affiliation with a group. Culture as a group identity is the way I most often think of culture, although I also study the politics and ideology and the performance of the enacted group identities. A communication event or interaction becomes intercultural when different cultural identities emerge in the text or talk of interactants." (Collier, 2003: 417)

\section{Religion}

The most important key-term we use in the article - religion - is, according to Merriam-Webster Dictionary defined as " $1 \mathrm{a} /$ the state of a religious, $1 \mathrm{~b} /$ the service and worship of God or the supernatural. (2): commitment or devotion to religious faith or observance, 2: a personal set or institutionalized system of religious attitudes, beliefs, and practices, 3 archaic: scrupulous conformity: CONSCIENTIOUSNESS, 4: a cause, principle, or system of beliefs held to with ardor and faith" (MerriamWebster Dictionary, 2020).

Encyclopedia Britannica describes the term "Religion" as "human beings' relation to that which they regard as holy, sacred, absolute, spiritual, divine, or worthy of especial reverence." (Encyclopedia Britannica, 2020). Usually humans think about divine with connection to their very existence - a matter of their life, but most importantly a matter of what is death and what happens after one dies - a fate of human being after death. In various traditions around the world, these questions,

\footnotetext{
XLinguae, Volume 13 Issue 3, June 2020, ISSN 1337-8384, ISSN 2453-711X
} 
concerns and ideas are expressed "in terms of one's relationship with or attitude toward gods or spirits; in more humanistic or naturalistic forms of religion, they are expressed in terms of one's relationship with or attitudes toward the broader human community or the natural world." (https://www.britannica.com/topic/religion ). The origin, conditions of human life and most importantly, the conditions of the life after death are described in sacred writings, sacred books (or a sacred book) speaking also about the ultimate authority, whether spiritual or moral. During the life on earth believers (or worshippers) take their part in "devotional or contemplative practices such as prayer, meditation, or rituals. Worship, moral conduct, right belief, and participation in religious institutions are among the constituent elements of the religious life." (Encyclopedia Britannica, 2020).

As both definitions, mentioned above, speak about religion, it is clear, that the definition of the term, the explanation of the term is widely based. C. Dawson classified two characters of all religions regardless of being primitive or modern: 1/ Faith on whatever mystical essences which determinate human behaviors, ways of life, daily life; 2/ This faith exists throughout intermediary (often supernatural, sacred) persons, things, places, etc. Even though Confucianism is philosophical, ethical, and political teaching, and Confucius is not a prophet, Dawson perceives Confucianism as religion (Confucian religion). In this sense, even Marxism could be considered an art of "religion" (Dawson, 1951: 75). In this sense can religion be considered a core of each distinct culture (Dawson, 1950) or even the relevant substance of culture (Tillich, 1967). Hebrew, Western, Arabian, Chinese, Indian, Russian cultures have their bases in religions such as Judaism, Christianity, Islam, Confucianism, Hinduism, and the Orthodox Church. Similarly, Theravada Buddhism is the spiritual pillar of the cultures of Thailand, Myanmar, Sri Lanka, Cambodia, Laos, or Tibetan Buddhism is the breadwinner of the Tibetan and Mongolian culture.

\section{Science}

Lindberg and Pingree point out and important fact. "The historian ... requires a very broad definition of 'science' - one that... will help us to understand the modern scientific enterprise. We need to be broad and inclusive, rather than narrow and exclusive... and we should expect that the farther back we go [in time] the broader we will need to be." (Lindberg, 2007: 3; Pingree, 1992). To define science simply and narrowly only with the notion and understanding of the 21 st century would be misleading.

Merriam-Webster Dictionary defines science as

" $1 /$ the state of knowing: knowledge as distinguished from ignorance or misunderstanding, $2 \mathrm{a} / \mathrm{a}$ department of systematized knowledge as an object of study, b/ something (such as a sport or technique) that may be studied or learned like systematized knowledge have it down to a science, $3 \mathrm{a} /$ knowledge or a system of knowledge covering general truths or the operation of general laws especially as obtained and tested through scientific method, b/ such knowledge or such a system of knowledge concerned with the physical world and its phenomena: NATURAL SCIENCE, 4/a system or method reconciling practical ends with scientific laws."(Merriam-Webster Dictionary, 2020)

This definition rightly supports the complex meaning of the word science. Science is, first of all, originally connected with a certain type of knowledge. To know, to have certain knowledge separates one from the state of ignorance of false understanding. Only later is science considered to be the pursuit of certain knowledge. In the oldest times, it was the science that was commonly communicated and shared - for example the knowledge of growing the crops or observing the natural events. From simple knowledge developed the complexity of abstract thoughts (calendars, building the 
dams or even building the pyramids, etc.). Special place in this area are reserved for elaborate mythologies and legal systems. Therefore, we can boldly claim that science, in a very broad sense, existed before our modern times and was a part of the thinking of many ancient civilizations (Grant, 1997). “... modern science is a discovery as well as an invention. It was a discovery that nature generally acts regularly enough to be described by laws and even by mathematics; and required invention to devise the techniques, abstractions, apparatus, and organization for exhibiting the regularities and securing their law-like descriptions." (Heilbron, 2003: vii)

\section{Science in Medieval Times - a very brief discourse}

Early Middle Ages were characterized by the Aristotelian approach (four 'WHY' questions) to inquiries on natural phenomena to explain the phenomena and the world scientifically (mainly his works - Physics and Metaphysics). Because of the political struggles, sadly, some of the ancient knowledge was already lost, or kept in obscurity. However, "the general fields of science (or 'natural philosophy' as it was called) and much of the general knowledge from the ancient world remained preserved through the works of the early Latin encyclopedists like Isidore of Seville" (Grant, 1996). Even Aristotle's original works were lost in Western Europe, only one text by Plato (Timaeus) was available to Latin readers. The work Almagest, written by Ptolemy and containing a geocentric description of the solar system, was also known and quite influential during this period.

Some of the Greek classical texts were preserved in the Byzantine empire during the time of late antiquity. Nestorians and Monophysites translated many Syriac texts. They also played an important role while translating some of the Greek classical texts into Arabic in the times of Caliphate, preserving and even improving some types of classical learning. (Grant, 2007).

Most of European tribes and peoples had become Christian by the end of eleventh century. "Stronger monarchies emerged; borders were restored; technological developments and agricultural innovations were made which increased the food supply and population. In addition, classical Greek texts started to be translated from Arabic and Greek into Latin, giving a higher level of scientific discussion in Western Europe." (Lindberg, 2007).

Medieval Times are also the era of universities emerging. The first university in Europe (the University of Bologna) had emerged in 1088 originating in theological education. A demand for broader and higher education comes in the picture. The number of Latin translations grew, especially from Greek, Arabic, and Hebrew. For example, Avicenna's Canon was translated into Latin (McGinnis, 2010). Catholic theologians were interested in the texts of Aristotle, Ptolemy, and Euclid (Lindberg, 1992), starting a new phenomenon called Scholasticism in western Europe, an attempt of synthesis of Catholicism and Aristotelianism, characterized by the scientific method consisting of three basic steps: observing, describing, and classifying guided by a strong focus on revelation and dialectic reasoning.

The era of Renaissance brought about new possibilities, challenges, new developments, especially in the scientific fields. For example, new developments in optics contributed to the improvement and development of technology (camera obscura and the telescope) offering a new point of view - perspective not only for the scientists, but also for artists (perspectivism).

In the sixteenth century, we notice wide development of scientific research in various fields. Copernicus refused the widely-accepted-geocentric model of the universe and formulated a new - heliocentric model of the solar system. This was based on a theory that the orbital periods of the planets are longer as their orbs are farther from the center of motion, which he found not to agree with Ptolemy's model. (Goldstein, 2016). Kepler challenged the notion that the only function of the eye is perception and

XLinguae, Volume 13 Issue 3, June 2020, ISSN 1337-8384, ISSN 2453-711X 
shifted the main focus in optics from the eye to the propagation of light. However, Kepler is best known, for improving Copernicus' heliocentric model through the discovery of Kepler's laws of planetary motion. He did not reject completely Aristotelian metaphysics but attempted to search for harmony of spheres (Cohen, 2010). We cannot omit Galileo Galilei, who is appointed as the father of modern science. He made innovative use of experimenting and in the field of mathematics.

New technology of the printing press helped greatly to publish many arguments, including some that disagreed with contemporary ideas of nature and natural sciences. Descartes and Bacon presented new philosophical arguments in favor of a new type of non-Aristotelian science. Descartes concentrated on individual thought and proposed an argument in favor of mathematics rather than geometry to study the nature. Bacon underestimated the contemplation and emphasized the role of experiment. He also questioned the Aristotelian concepts of formal cause and final cause and promoted the idea that science should study the laws of 'simple' natures. He also argued for the very practical use of science aiming for the improvement of human life.

\section{Relationship between science and religion in Europe (a historical outline)}

There is not enough space in this article to speak about the place of science and the relationship of science and religion in Europe because of its complexity and very long and complicated background. Therefore, we need to touch only briefly on the problematic, which is necessary, though, because of the common misconceptions about it ending many times in caricatures portraying a false image of this relationship in the present era. The most common, or most widely used view of science and religion is, that they are in eternal and irreversible conflict with one another, a view that is an artifact of a few well-known historical examples that have served the agendas of political and social activists. (Ferngren, 2017: 3). It is obvious that the terms 'science' and 'religion' have been used extremely broadly. Depending on the time, place, and context, they can refer to completely different things or phenomena, and as a result, they can easily become barriers to a deeper and clearer understanding. (Ferngren, 2017: 4)

The relationship between religion and science has a long history of debate in human history. In pre-Christian Europe, it seemed that rudimentary, what we would consider 'scientific' today, knowledge could co-exist together with primitive animism and shamanism. But in the later period of human history, when both religion and science became more developed with the diversity of their forms, especially with the appearance of Christianity, the relation between religion and science became more dynamic. Tertullian (155-240), the first Latin theologian and early father of the Christian Church who had said that "prorsus credibile est quiaineptumest" (It is inevitable because it is impossible) (De carne Christi, V, 761B), appeared to be hostile to philosophy and rationality. "What has Athens to do with Jerusalem?" he asked (enter the quote). It might seem that Tertullian ignored any role of scientific knowledge and defended Christian faith: "The blood of the martyrs is the seed of the Church" (Apologeticus, Chapter 50).

Before we get deeper to the main subject of this part, we need to clarify what we mean when we talk about medieval 'science.' It would be misleading to think about science in the medieval period of time corresponding even approximately to, what we mean by modern science today. We can speak about the roots or sources or even beginnings of science in the Middle Ages, the basis for later modern scientific disciplines and practices. Medieval scientists, scholars, had ideas about nature, they were using certain methods for exploring it, and appropriate languages for describing their findings. Many of these ideas, methods, and languages were drawn from the classical period of time (as we have mentioned already above), during which the nature was closely connected with thoughts about other subjects. To think about nature and other phenomena belonged to the realm of philosophy. "Natural 
philosophy, science, and natural science" were considered as synonyms. In this period, natural philosophy closely and uniquely interacted with Christianity as a natural part of philosophy. Therefore, we can speak about close interaction of science and religion during Middle Ages, about theologians as highly educated scholars, who owned beliefs about science and theology. All medieval scholars were both theologically and scientifically educated, and all understood that theological beliefs necessarily entailed scientific consequences. Scientists and theologians were often the very same person, educated in the full range of medieval disciplines. They were almost perfectly capable of dealing with scientific and theological matters of their present time and generally able to find ways of integrating both, theological and scientific belief. (Ferngren, 2017).

The famous theologian, Thomas Aquinas (1225-1274), would be a good example of such case. He had a notion about double truth defended by Siger of Brabant (12401284) and the Latin Averroism. One of the double truth is the philosophical and rational truth of human knowledge about nature. The other is the truth of faith in God's kingdom, in paradise and hell, about the transcendent and supernatural sacred world. Basing on scholasticism, Thomas Aquinas emphasized Christian faith but did not ignore absolutely the role of rational scientific knowledge. This concept of a double truth was revived in the Renaissance, where pantheist theories about the relation between God and nature dominated.

It is only in the 19th century where this co-existence ends. Andrew Dickson White in his work "A History of the Warfare of Science with Theology in Christendom" written in 1896 eagerly argued that Christianity had a long history of opposing scientific progress in the interest of dogmatic theology. Another famous author William Draper (History of the Conflict between Religion and Science, 1874) also influenced American thinkers who agreed with secular outlook and recognized the central role of science within the context of modern society. Both books were used to create, so called, Draper-White thesis to emphasize irreconcilable conflict between science and religion later in the $20^{\text {th }}$ century, which was predominant in the $19^{\text {th }}$ century and for some time in the $20^{\text {th }}$ century. It presented triumphalist view of science and a very dismissive view of religion. Science was, according to it, continually progressing, Christian faith continually retreated. Religion, based on faith, seemed to lose, when confronted by science, which claimed to be based on pure facts. Currently many historians, scientists and theologians consider this Draper-White thesis as way oversimplifying and quite distorting to a complex and a very dynamic relationship of science and religion. Later in the $20^{\text {th }}$ century the thesis was systematically reevaluated. According to the new findings, ever existent relationship of science and religion must be regarded much more positively. Popular images of eternal warfare and controversy continue to exist, promoting supposed hostility of Christianity to new scientific theories. Contemporary theories have shown that Christianity has often nurtured and encouraged scientific endeavor, whole at other times the two have coexisted without too much tension or attempts at artificial harmonization. Christian understanding of the world and human existence exists in European scientific and philosophical thought predominantly until the twentieth century. "If Galileo and the Scopes trial come to mind as examples of conflict, they have proven to be the exceptions rather than the rule." In the words of David Lindberg, writing on medieval science and religion for the earlier edition of this volume, "there was no warfare between science and the church. the story of science and Christianity in the Middle Ages is not a story of suppression, nor of its opposite, support and encouragement. What we find is an interaction exhibiting all the variety and complexity that we are familiar with in other realms of human endeavor: conflict, compromise, understanding, misunderstanding, accommodation, dialogue, alienation, the making of common cause, and the going of separate ways." (Ferngren, 2017: xi-

XLinguae, Volume 13 Issue 3, June 2020, ISSN 1337-8384, ISSN 2453-711X 
xii). (old myths die hard!) Traditional picture of Galileo as a victim of the Catholic Church and its disgust to real science might become a caricature, if not put into proper context. Similarly, Isaac Newton, was not only a great natural philosopher, but he also had a deep interest in theology and biblical prophecy, which created a framework for his scientific discoveries. "Finally, Charles Darwin has been portrayed in recent historical studies as a man who, alongside the discoveries in scientific theory of natural history, struggled with very personal religious issues and was profoundly influenced by the tradition of natural theology" (Ferngren, 2017: xiii).Paley's view is complemented by Whitehead's emphasis on the complexity and dynamism of religious traditions as such, when he says:

"Both, scholars and theologians have long recognized that religious traditions are neither monolithic nor static - that they have developed over time and reflect the diverse circumstance of their geography and culture. Failure to understand this historical reality has led those who ... see controversies between science and religion as disputes in which religion was always wrong, and ... science was always right. The true facts of the case are very much more complex, and refuse to be summarized in these simple terms" (Whitehead, 1960: 163).

Today we often find ourselves in the real danger of 'presentism and essentialism,' which is irresistible tendency to shape the past by employing modern definition and understanding assuming that the basic idea of certain discipline or term is (and means) all the same throughout all the ages. It is as if both of them remain universal and unchanging throughout the ages. Obviously, there is no such possibility of any essence that remains constant across time and space. It is undeniable fact, that terms 'science' and 'religion' have had different meanings throughout the history. To impose our modern definitions on the study of the past and to admit as truly scientific only what a modern scientists would regard as such, surely distorts the history of science. Religion and science are both historically and socially conditioned. In any case, we agree with Mongrain (2017: 34) that "a unified truth that includes science and the Christian religion within a neutral philosophical theory is damaging to the life of faith. It offers people a counterfeit version of Christian wisdom that requires neither purity of heart nor love; seeing 'nature' as 'creation' requires more than a conceptual amending of Darwinian science with a Thomistic theory of final causes." It is also important to notice that before 1600, neither the word 'science' nor the word 'religion' had the meaning we currently ascribe to the terms. 'Scientia' and 'religio' originally referred to very different concepts that we ascribe to the words today. We think of science as a way of knowing and religion as a set of beliefs and practices related to worship. In the Middle Ages the terms referred to interior qualities of a person, virtues to be cultivated. Scientia was described as a carefully developed habit of mind related to logical demonstration and problem solving and tied to moral excellence. Religio referred to interior acts of devotion and prayer, to behavior that is based on these inner motivations.

One needs to be truly aware of the cultural limitations that are imposed on all societies, ideas and disciplines, including our own. It is hard for us, just as for any other generation, to accept, that the modern age is also a historical period, limited in its perspectives by space and time and subject to the constraints of its own zeitgeist. We have historical and cultural limitation which force us to view the past in a manner that is neither patronizing nor disparaging, but instead capable of appreciating the power of ideas that we do not share or that have fallen out of fashion in our own day. (Whitehead, 1960).

\section{Religion and Vietnamese traditional culture}

Vietnam is a multi-religious country. Vietnamese are usually very proud of their long literate tradition. The Confucian Temple of Literature (Van Mieu) in Hanoi, which 
was established in 1076, was the first university in Vietnam. Buddhism was a state ideology in Vietnam from eleven to fourteen centuries. After a thousand years under Chinese occupation, Buddhist pagodas were the early centers of education and culture. Some Buddhist monks such as Khuong Viet (933-1011), Van Hanh (938-1025), Huyen Quang (1254-1334), Phap Loa (1284-1330) became advisors in political affairs of the court. It was well-known that Tran Nhan Tong (1258-1308), the third king of the Tran dynasty, established a new Buddhist Zen branch of Truc Lam Yen Tu. However, Mahayana Buddhism was introduced into Vietnam, mainly from China, in the early centuries of the Common Era. Unlike Confucians who wanted to turn Vietnam into a Chinese model, Vietnamese Buddhism and an independent Vietnamese state were the main motivations of the first generations of Vietnamese Buddhist monks (Nguyen, 2010: 184-396).

Since the fifteenth century, under the Le and the Nguyen dynasties, the role of a state religion was replaced by Confucianism.

"Boys were supported to begin their schooling at the age of seven, the age of eight by Sino-Vietnamese reckoning. At the age of eleven, they first applied themselves to the Analects of Confucius, Mencius, the Doctrine of the Mean, and the Great Learning. At the age of fourteenth, having finished the Four Books, they read the Classic of Songs, the Classic of Documents, the Classic of Changes, the Record of Rituals, the Spring and Autumn Annals, and the earlier Chinese dynastic histories" (Woodside, 1971: 189).

The syncretism of three teachings (tam giao, Confucianism, Buddhism, Taoism including native religions and faiths), has been a spiritual basis of Vietnamese traditional culture. They are the three pillars of Vietnamese traditional culture.

It was un-doubted that educational systems in pre-colonial Vietnam, in fact, were generally Buddhist and Confucian. "Minh Mang may well have been the first man in the East Asian classical world to observe that the examination system could not prepare Chinese or Vietnamese societies for their looming confrontation with the military powers of Europe" (Woodside, 1971: 224-225), but he was not in situation to change this Confucian education and exam system. There were some Chinese algebra and mathematics, but there was neither rational science nor experimental scientific systematical knowledge. In general, in pre-colonial Vietnam, there was not a science in Western meaning. There was not also an extreme antagonism between religious and primitive scientific knowledge. Unlike in the West, because of Confucian secularism in Chinese-Vietnamese culture, we see a relatively flexible relationship between materialism and idealism, between atheism and theism, as well as between religiosity and secularism in Vietnamese traditional spirituality.

But that does not mean that there was only an absolute harmony between Western science and Confucian traditional values. In the nineteenth-century, Nguyen Duc Dat wrote in Nam Son tung thoai that Confucianism alone is enough for Vietnamese, that we could find in four books and five Classics an explanation for everything. It was undoubted that the rule of Confucian world outlook and self-sufficing agriculture were the main reasons for an underdeveloped scientific knowledge in pre-colonial Vietnam.

Religious life in Vietnam became more diverse since the Christian mission in the seventeenth century. Western ideas, including some knowledge of natural science, were introduced into Vietnam. It was undoubted that the Christian mission was a bridge between Western and East Asian ideas. European missionaries had played an essential role in creating a Latin-based-alphabet for the Vietnamese language. But together with Christian mission, there was the first clash between European-Christian values and Vietnamese Confucian traditional cultural and religious rituals. That is why it is not surprising that Christian prohibitions were issued in the seventeenth and

XLinguae, Volume 13 Issue 3, June 2020, ISSN 1337-8384, ISSN 2453-711X 
eighteenth centuries, especially in the nineteenth century under the Nguyen dynasty. That was not only because Christians wanted to carry out monogamy, gender equality, or even the fact that Vietnamese Christians were not allowed to carry out their ancestor worship. The conflict, in reality, was more serious: a Confucian court could lose their legitimacy if Vietnam became a Christian country one day. A Confucian Son of Heaven did not accept the fact that Vietnamese Christians do not follow him firstly but Christ.

"The traditional Vietnamese order could not tolerate such evangelism, because Vietnamese institutions were based not upon the modern Western concept of the separation of church and state, but upon the concept of the state as the political expression of the elite, would obviously, qualify the nature of elite ideology" (Woodside, 1987: 135).

Also, a gap between Christianity and native religions and beliefs was more prominent than that among native religions and faiths themselves. There was no cultural background for Western science development in pre-colonial rural Vietnam: "As of 1839, the Vietnamese elite, led by Minh Mang, exhibited a naïve optimism that Western technology could be privately appropriated by Vietnamese artisans without their having to cross any cultural barriers. The existence of Western machines was recognized empirically before the existence of Western scientific culture as acknowledged philosophically" (Woodside ,1987: 133).

There is a debate on whether Vietnamese are religiously pious or impious. Here we see Tran Trong Kim versus that of L. Cadiere. According to Tran Trong Kim, Vietnamese have usual behaviors towards worshipping but are not devout with any religion (Tran, 2003: 16). Tran Trong Kim was right when we analyze the fact that Vietnamese usually do not spend much time on their religious worship like Hindus or Muslims. Furthermore, they are polytheists and relatively tolerant concerning their religious life. Vietnamese pagodas worship not only Buddhas and Bodhisattvas but, in many cases, also some other Taoist and native deities. It is not rare for many Buddhists to visit Taoist temples.

On the contrary, L. Cadiere emphasizes the fact that Vietnamese cannot live without the presence of religious faiths in all important events of their life cycle: birth, marriage, death, etc. It is when a Vietnamese has troubles in his daily life that people get to see which religion he or she really follows. Vietnamese people believe in Buddhist karma. From the viewpoint of Confucianism and folklore faiths, ancestors can give their relatives blessings or punishments depending on their behaviors toward their ancestors. Therefore, people worry about punishments if they do something wrong with their ancestors. That is why Vietnamese are pious, according to Cadiere (Cadiere, 2010: 48).

The debate between Tran Trong Kim and L. Cadiere expresses some paradoxes in Vietnamese spirituality. On one side, Vietnamese are active in worship, but on the other side, they are not enthusiastic about any religion and faith. Vietnamese culture is religious, based on the syncretism of the 'three teachings' (Confucianism, Buddhism, and Taoism), but is also secular. Different from Theravada Buddhists in Sri Lanka, Thailand, Laos, or Cambodia, Vietnamese usually pray to Buddha for their health or something worldly rather than for salvation in Nirvana. Due to the secularism of Confucianism, Vietnamese traditional religious life has many secular aspects. It is questionable whether they have religious faith in a theological sense. Another paradox is that while Vietnam is multi-religions, a spiritual vacuum still exists. All 'three teachings' are not native. Every exotic culture and religion can be introduced into this country because Vietnamese are not enthusiastic about any religion and faith: "Burdened as he was by a Chinese-style worldview in an environment which daily contradicted it, it was amazing that the Vietnamese ruler maneuvered as much as he did. If it was true that Vietnam never completely conquered the difficulties of domesticating the Chinese institutional model, it was also true that the Chinese 
model's influence never completely stifled Vietnamese ingenuity" (Woodside, 1971: 294).

\section{Western science in colonial and post-colonial Vietnam: Religiosity versus secularism}

In Vietnamese tradition, the relationship between religious faiths and native knowledge was only relatively similar to that in pre-Christian Europe. However, the situation had changed due to Christian mission and Western ideas and cultural values introduced into Vietnam. Since the colonial period, a secular state and education system following the French model was established. The relationship between religion and science since then became more complicated. By the end of the nineteenth century, there were two parallel educational systems. Besides a thousand years long traditional Confucian education, there was the first time in Vietnamese history a secular education system that followed a Western model. Besides the traditional Confucians, there was a new intelligence stratum that was under the influence of Western education. In 1906 the Indochina University (Vietnam National University in Hanoi today) was established. It was the first university that provided Western education. A short time later, a college of medicine was also established. Western medicine existed in parallel with traditional treatment. Intellectuals who followed Western education took different positions within the government in both colonized areas and the area under the Nguyen. Rulers played a significant factor in increasing or decreasing the gap between religion and science. In sum, the French colonial regime had tried to reduce conflicts between Western and Vietnamese traditional values and rituals. Colonial authorities did not hinder traditional religions and faiths rising in the consequences of the collapse of a Confucian bureaucrat. The Buddhist rebirth, as well as the appearance of Cao Dai and Hoa Hao religions in the first half of the twentieth century, did not really meet hindrance from secular authorities. After a long discussion, there was no separation between state and church in French Indochina as it was in France in 1905.

On the other side, Vietnamese society did not avoid secularism as the fruit of the French revolution. Secularism in Vietnam became more extreme when Marxism was introduced. While Marxism had no opportunity to gain influence in Islamic societies, it did not face much difficulty in becoming a power in China and Vietnam. Confucian secularism was one of the main reasons for such popularity of Marxism as well as of communist parties here. In 1930-1950 Marxists in Vietnam used Confucian terminologies to introduce Marxist ideas. Loyalty to the emperor was transformed into allegiance to the communist party. Piety to parents and ancestor, which was only second to loyalty to the emperor in Confucian society, was transformed into piety to workers and peasants' class. Nguyen Khac Vien emphasized the similarity between Confucianism and Communism as they both stressed the collective community against "capitalist personalism" (Nguyen, 1995).

Truong Chinh, in his book The Outlines of Vietnamese Culture (De cuong van hoa Viet Nam, 1943), had emphasized that Vietnamese culture is socialist and irreligious. There was a significant influence of the Marxist theory of class struggle in his writing, especially when he said that the communists should fight Confucius and Mencius' ideas and for the victory of dialectical and historical materialism. During 1946-1949 even though Ho Chi Minh had called for solidarity between Christians and nonChristians, the communists carried out a discussion in the newspaper Truth (Su that) on whether God exists or not. They had propagated the materialist worldview and the victory of science over the religious outlook. The communists promoted Marxism as a scientific theory. From the viewpoint of Marxism, all God and ghosts are nothing more than illusions. All things in this world consist of pure material. There is only one material world, and there is nothing else. 
After 1945, the colonial education was abolished, but there was no movement against Western science itself. The authorities stand behind the relation between Western science and traditional religions. They nationalized all schools of religious organizations with the purpose of building a socialist, atheist state. There was a collective movement against superstitious and feudal remnants. Thousands of pagodas, temples, and religious places were destroyed. Materialistic and scientific worldview became synonym words. Materialistic and atheist state schools introduced Western science following the Soviet model and propagated the victory of science, materialism, and atheism.

Marxist view of radical antagonism between science and religion was introduced into Vietnam during the colonial period, and together with it the materialistic and atheist ideas. From a Marxist viewpoint, materialistic and scientific worldviews are almost identical. Religion was considered as an idealist and anti-scientific worldview. A secular essence of science is emphasized and considered as fundamental of materialist outlook. The distance between religion and science was extreme.

During 1953-1957, the North Vietnamese communist regime carried out land reform. Although, in theory, they would like to classify landlords into anti-revolutionary, normal, and patriotic ones, in reality, all lands of pagodas, temples, and churches were also confiscated. There was an exodus of almost one million North Vietnamese into the South; two-thirds of them were Christians. The government of North Vietnam sent thousands of students to study in the former Soviet Union and other socialist countries in East Europe, where an approach of secular, rational science was dominated.

After 1957 and during the Vietnam War, communists carried out a movement against all traditional religions and faiths as superstitious rituals and behaviors and residues of feudalist society. Thousand pagodas and temples were turned into department stores, classrooms, storage, and so on. At schools, the curriculum propagated about the victory of materialism, atheism as well as that of a scientific outlook on religious virtues. In this way, hundreds of pagodas and temples were directly or indirectly destroyed.

The so-called "fighting against all superstitious rituals and behaviors" was carried out in all fronts, even among minority groups in the whole territory of North Vietnam. Many native religions and faiths were considered superstitious and anti-socialist elements. In the values scale of Marxists, Buddhist monks and Christian clergies were classified as unproductive and even sponged groups. Thousands of herbalists, magicians, geomancers, elders, etc. who were traditional intelligentsias were abolished. Religion and faiths in the eyes of Vietnamese communists were considered as symbols of a backward society, while science and technology become symbols of a progressive society. It was undeniable that North Vietnam authorities at that time were under the influence of Mao's Cultural Revolution in China. Hundred traditional festivals that included traditional cultural and religious activities were prohibited.

In sum, the authorities in North Vietnam promoted a concept of contradiction or antagonism between religion and Western science. It was described simply as an antagonism between idealism and theism on one side, and materialism, and atheism on the other side. Therefore, for many Vietnamese, not only religious values but also traditional cultural values were ignored.

Throughout the pictures of China and Vietnam, especially in the post-colonial period, it seems that there was an antagonism between Western science and East Asian Chinese and Confucian traditional culture. A harmonious relationship between them sounded impossible. The two countries fell into a dilemma: they had to choose between the growth of science and technology and the preservation of their traditional cultural and religious values. That antagonism was not the natural outcome of the relationship between Western science and Vietnamese traditional culture at that time but largely the result of some political propaganda by the communist authorities. The authorities wanted to reduce the influence of Vietnamese traditional religions and 
faiths not because they wanted to develop Western science and technology, but because they were promoting the triumph of Marxist doctrine over feudal and colonial vestiges:

"Secularization and religious revival throughout the region have forced the elites of Southeast Asia to look at religion in different ways. The attachment of elites to a new gospel of science-based on 'progress,' for example, has led many to make distinctions between 'religion' (by which they mean scholarly, intellectually higher religions), on the one hand, and 'superstition' (by which they mean less scholarly, more autonomous forms of popular religious thought) on the other. Traditional Asian rulers, even in colonial times, would not have made such a distinction. In Vietnam in the 1980s, however, Buddhism is no longer seen as a single spectrum of higher and lower traditions, both of which may be involved in peasant life. The government, however, is hostile to manifestations of popular millenarianism, even those who are wholly nonpolitical" (Woodside, 1987: 465).

It is not easy to talk about harmony between Western science and Vietnamese traditional culture when we analyze environmental and ecological consequences in post-colonial and contemporary Vietnam. Traditional Vietnamese were under strong influences of Taoist conception on periodic and ecological nature. "Heaven gave birth to elephants, so earth gave birth to grass" (troi sinh voi, dat sinh co) is a Vietnamese saying. Being harmonious with nature was the lifestyle of a traditional Vietnamese. You will have to face the punishment of nature if you do not respect it. Then a concept of 'conquering nature' was introduced into Vietnam and became a motive of the communist regime.

As the consequences of modernization and industrialization in the last decades, nowadays we see not only the population explosion and urbanization but also a 'consuming culture,' a new lifestyle, which tends to underestimate environmental and ecological issues. There was almost no city planning in both theoretical and practical points of view in Vietnam before the threshold of the third millennium. The conflict between Western science, technology, and Vietnamese traditional culture becomes more serious than it should be. Green bamboos, the symbol of every village in Red River Delta, becomes a story of the past. State policy for 'foreign investment in any case' did not face any challenges before the Formosa environmental crisis occurred in the central coast last year.

It was true that there was not a Western science uprising in Vietnam before Renovation (Doi Moi). That was the difference between the situation in China and Vietnam and that in Taiwan, South Korea, and Japan at the same time. But it was also true that the communist authorities had used Western science as an argument against Christian churches, traditional worships, and all feudal vestiges in their eyes. It is not surprising that the gap between Western science and Vietnamese traditional culture and religion before Renovation was more significant than that was during the colonial period.

All those remarks of religious life in traditional pre-colonial Vietnam, as well as secularism in the colonial and post-colonial period, are crucial factors which have influences on the relationship between religion and Western science in the last centuries in the country. From the viewpoint of religiosity versus secularism, the clash between religious faith and scientific knowledge in colonial and post-colonial Vietnam was more significant than that was in the traditional pre-colonial period.

But that is only a side of the issue. However, there were not extreme phenomena of religious organizations against scientists like in the West. Due to Confucian and East Asian secularism, the conflict between religion and Western science is not so sharp as

XLinguae, Volume 13 Issue 3, June 2020, ISSN 1337-8384, ISSN 2453-711X 
it is in the West. If Marxism was introduced to Vietnam on the so-called Confucian 'chariot' vehicles, so the Vietnamese communists are not atheists like their comrades in Europe. They could not shake off their ancestor worship and traditional culture from thousands of years of their people. Although most of them stated that they were not religious according to the instructions of the Communist Party, but in fact, in their spiritual life, they were still rather polytheists than none-religious in the end. Thus, even though officially, Marxism considered religion as an 'opium for the people,' but to be able to integrate into Vietnamese East and Southeast Asian society, to dominate the way of thinking of the Communists, Marxism was forced to be tolerant of Confucianism, Buddhism, and indigenous religions, and that will stamp out any antagonistic ideas between science and religion.

\section{Western science and Vietnamese traditional religion: Rationalism versus none- rationalism}

Vietnam has a long literate tradition. Irrationalism was dominated in the traditional Vietnamese way of thinking. It is well-known that there were not great thinkers in Southeast Asian nations, including Vietnam. One reason is the fact that ancient Southeast Asia, apart from the Philippines, was not a great civilization itself, but only the periphery of two great civilizations of China and India (Benda, 1972: 127). In Vietnam, there were several famous Buddhist thinkers such as Phap Loa, Khuong Viet, Tran Thai Tong, Tran Nhan Tong, Huyen Quang and Confucian thinkers such as Nguyen Trai (1380-1442), Nguyen Binh Khiem (1491-1585), Le Thanh Tong (14421497), Le Quy Don (1726-1784) Ngo Thi Nham (1746-1803) and so on. There was a syncretism of Confucian, Buddhist, Taoist, and native thoughts. "In the Sinicized orbits the 'separation of state and church' (i.e., the ultimate supremacy of the Confucian mandarinate over the Buddhist monks) at times seems to have brought the monks closer to the peasantry, without, however, endowing Vietnamese peasant religion with a lasting, let alone profound, Buddhist element" (Benda, 1972: 131).

During the colonial period, there were some famous reformers who tried to combine both Vietnamese traditional and Western ideas such as Nguyen Truong To (18281872), Truong Vinh Ky (1837-1898), Phan Boi Chau (1867-1940), Phan Chu Trinh (1872-1926). After the Russian-Japanese war, there was a debate among Vietnamese thinkers whether Vietnam should follow either East Asian traditional or Western modern models. Pham Quynh (1892-1945) and Nguyen Van Vinh (1882-1936) defended Western model and Enlightenment ideas meanwhile Phan Boi Chau and Tran Trong Kim (1883-1953), who considered Japan as an ideal model, believed that Vietnam could modernize and industrialization basing on its Confucian legacies. Ho Chi Minh, in his Declaration of Independence in 1945, had cited the United States Declaration of Independence and the French Declaration des Droits de L'home et du citoyen. It showed that Western ideas could be accepted as important components of modern Vietnamese culture. However, the conquest of communists and the building of socialism following the Soviet model ended this debate in the following periods of Vietnam history.

In the thousand-year history of pre-colonial Vietnamese thoughts, there was not any tradition of theoretical thinking but only native knowledge based on mass experiences. According to Leopold Cadiere, in this country, there was not a Vietnamese academic theoretical philosophy, as we usually see in the Western tradition, but only a Vietnamese practical folklore philosophy which usually based on an irrational way of thinking. There was not really a theoretical rational thinking tradition in this country. What is called Vietnamese philosophy is, in fact, only a modification of Chinese philosophy, also Confucian, Mahayana Buddhist, and Taoist legacies. Even Vietnamese literate did not have many debates and theoretical speculations. They simply accepted all, what Chu Hsi had understood, and explained about thoughts of Confucius and Mencius (Cadiere, 2010: 48). 
L. Cadiere was right. Vietnamese culture was also under some influences of Indian philosophy when Viet people expanded to the South (namtien). However, Buddhism and Hinduism composed only some important components but not the spiritual basis of Vietnamese culture. The same idea can be found in another author's work. Ha Van Tan admitted that there was not a theoretical science nor philosophy in the Western meaning in Vietnamese history. Vietnamese in many generations did not have a theoretical thinking tradition. Their living conditions did not usually base on science and technology development. Furthermore, they did not have opportunities to create rational scientific theories because they had to spend all their time to fight for Vietnamese national independence. Vietnamese have only so-called 'left hand' philosophers or practical philosophy (Ha, 1984: 29). The Vietnamese way of thinking ways is an experiential one.

By the end of the 1970s, there were some conferences to discuss whether the Vietnamese have their own philosophy. In general, most authors agreed that there was not a tradition of theoretical thinking, not philosophy, as a system of thoughts as we saw in the history of Western philosophy. There were only some philosophical and theoretical speculations, but not any pure and original philosophical works in the history of Vietnamese thoughts as a tradition (Tran, 1973: 10-11). There is also a consensus that Vietnamese did not have a history of philosophy in Western meaning, but only a history of Vietnamese thoughts, including some philosophical ideas (Le, 1984: 58-62). However, one may have a question: why Vietnamese people cannot say about their philosophy while in their neighborhood, people talk about Japanese philosophy and Korean philosophy? Most authors showed caution in using the term 'Vietnamese philosophy.' The term 'philosophy' has different meanings, and in any case, Vietnamese do not have it as a systematic metaphysical theory.

The fact is, an intuitive, sometimes irrational, philosophizing (minh triet) had dominated the traditional Vietnamese way of thinking. However, the situation had changed when Western science was introduced with the establishment of universities and research institutions in Western-style. The contradiction between rationalism and irrationalism was not new in Vietnam, but that was also a story in the past. "Proud of their rationality, the Vietnamese Confucian elite reacted with hostility to what they regarded as the irrational superstitions of the French Roman Catholic missionaries who were arriving increasingly in Vietnam as early as the seventeenth century" (Woodside 1987: 131). There was not personality as well as personalism in precolonial Vietnam, as we see in Europe after Reformation. Person and personalism usually appeared only in urban society, not a rural one. In a Confucian society, there was only a family, not civil relationships, as we saw in modern Europe. That family, not an individual, was a social cell. From this point of view, Vietnamese society was only a great Vietnamese family (Tran, 2001: 294-295).

The situation changed gradually during the colonial period:

"This new era is characterized by increasing, and ultimately decisive, Western influences upon Southeast Asian society. In at least three significant aspects, these influences differed from those of earlier times. In the first place, they originated in industrialized nation-states of the Atlantic community rather than either feudal monarchies (...) Second, and no less important, they came to envelop virtually all of mainland and island Southeast Asia with the exception of Siam (...) Finally, while the consolidation of Western control brought law and order to wide areas and, with it, a virtual cessation of dynastic and inter-principality rivalry and martial "interaction," the era of modern colonialism (...) Westernization has nonetheless provided a kind of intrinsic unity, which has tended to de-emphasize some of the major 
historical differences between the Indianized, Sinized, and Philippine segments of Southeast Asia" (Benda, 1972: 142).

After 1919, the traditional Confucian court exam was replaced by a new colonial exam system in Vietnam. Some Western works were also introduced. It was the first time the Vietnamese got to know about the ideas of Western authors such as R. Descartes, C. de Montesquieu, J.J. Rousseau, I. Kant, F. Nietzsche, etc. Together with them, the works of European writers such as Victor Hugo, Denis Diderot, La Fontaine, Alexander Dumas, W. Goethe, etc. were introduced. Some intelligentsias had an opportunity to study in Europe, especially in France, among them some famous scholars in social sciences and humanities such as Ta Quang Buu, Nguyen Van Huyen, Pham Quynh, Nguyen Van Vinh. The first half of the twentieth century was a golden time for the development of Western social sciences in Vietnam.

Unlike the colonial period when there were mostly social sciences and humanities development, communist Vietnam, following Lenin's formula 'socialism is soviet government plus electrifying in the whole country,' had a clear policy to develop natural sciences even during Vietnam War. Developing a socialist society demanded industrialization and modernization with the establishment of universities in the field of poly-technique and economics. A system of entrance examinations into universities and colleges was created with a focus on natural sciences. In the colonial period, there were also some famous scientists of natural sciences and technology. But only during the Vietnam War, those disciplines were focused and had considerable development following the Soviet system. Both the Vietnamese Academy of Natural Sciences and Technology and the Vietnamese Academy of Social Sciences were established in the 1950s. Thousands of students were sent to study abroad, mostly in the former Soviet Union and communist countries in East Europe. It was also carried out intensively after the unification in 1975. Since the collapse of the communist blocs, Vietnam has been more active in cultural and educational exchanges with Western countries and international organizations. Vietnamese government now tries to build a state with the rule of law to replace the traditional society, which is still quite heavily under the influence of Confucian morality. Due to secular education in universities since the colonial period, although there is not yet an intelligentsia stratum in contemporary Vietnam in the modern meaning of this term, it is true that the intellectuals now have more ideological freedom than Confucians in the past.

However, due to Western science and industrialization, soon, Vietnam was no longer a rural and village country as it was in the eyes of researchers. There has been a transformation in this society since Renovation (Doi Moi). On one side, it is undoubted that due to Western science and technology introduction in the last two centuries, Vietnamese now have not only a living standard improvement but also a more rational and theoretical way of thinking than their ancestors. As a consequence, the clash between traditional religious beliefs and scientific knowledge has also become more prominent than that was in their traditional situation. But on the other side, in the context of Southeast Asian none-institutional polytheism and syncretism relation between rationalism and intuition is something different from that in the West. Note that Southeast Asian indigenous elements are a significant factor. Any ideology and religion that has been introduced from outside here have been 'softened' so that it can take root in Southeast Asian society. Hinduism in Champa and Bali is different from Hinduism in India. In the case of Catholicism to accept ancestor worship, this region's Islam is not as extreme as it is in the Middle East and North Africa are other examples. However, despite the great efforts of colonial and post-colonial governments, the poor development level of Western science in Vietnam is not strong enough to put scientific and theoretical thinking on the position to dominate the thinking way of the elite. It has not had a far-reaching influence on the 'intuitive' lifestyle of the Vietnamese people for a long time. It is, therefore, wrong to speak about the antagonist contradiction between rationalism and irrationalism in Vietnam. 


\section{Conclusion: A Comparison of the Relationship between Science and Religion in East Asia and Europe}

The relation between religious belief and scientific knowledge in East Asian culture is something different from that in Europe. There was some scientific knowledge but not science in pre-colonial China. Marx Weber was right when he found that Western terminology was not adequate with Chinese culture. He explained why, in precolonial China, there was not modernity and capitalism. Different from Christian God, Confucian Heaven is not the Creator of this world. Unlike in Western culture, in Confucian spirituality, there was only a relative distance between men and deities, between natural and supernatural worlds. Therefore, contrary terms such as materialism versus idealism, atheism versus theism, as well as monotheism versus polytheism in Western culture does not seem to fit with Chinese and Vietnamese culture.

While the emergence of Protestantism caused the emancipation of personalism in Europe, Weber found out that the concept of a person in the Confucian world did not exist. Weber analyzed why capitalism, as well as a rational science, could not rise in pre-colonial China. Confucian education was secular with the focus on ethicalpolitical training for people to become state officials at both central and local levels. In a Confucian society, there were four strata: Confucians, peasants, handicraftsmen, and business people. The criteria for this social classification was not their economic condition or living standard, but Confucian moral doctrine. The literate stratum was, in reality, not intelligentsia in Western terminology because they learned and did court exams not for becoming the pure theoretician or researchers with demand for ideological freedom, but to be the court mandarins of different ranks (Weber, 1988: 290).

The most important virtue for all Confucians was loyalty to their emperor, the Son of Heaven. The Son of Heaven is the symbol for the state and all people in the country. Only the emperor is the real host of his country and people. Loyalty to the emperor was significant for patriotism. In traditional China, there was no concept of nationalism similar to the Western meaning. In the pre-colonial period, the Chinese had neither mathematics nor natural science, but only astrology and geomancy. There was no democracy, social equality (including gender equality), as became commonly known in Western terminology. Hegel said that the Chinese had no idea about liberty and freedom. In ancient Chinese society, only the emperor had the privilege of freedom. The concepts of liberty (freedom) and equality in Western meaning were introduced to China since the colonial period. Confucian rationalism is also very different from rationalism in Western meaning, where both logical theoretical and intuitive experiential levels of thinking are correctly classified. Confucius was not a prophet, and he did not think about the question of whether another world exists or not. He speculated only about this world and did not say about what happens with men after their death. However, he did not doubt the perpetual existence of human souls. Weber found that because of being secular, Confucianism could not exist alone. Dawson pointed out that there was a so-called 'spiritual vacuum' in the heart of Chinese culture (Dawson, 1951: 230), and it needed Buddhism and Taoism as its unofficial supplementary teachings. The relationship between religion and science in pre-colonial China and Vietnam was similar to that in pre-Christian Europe.

In Western culture, as well as Chinese and Vietnamese cultures, there are wide gaps between religion and science, at least in two dimensions. The first dimension points out religious faith conflicting with secular scientific knowledge. (Schockenhoff, 2014) In any case, religious belief does not exist without a sacred essence. On the opposite, scientific knowledge is secular and has the purpose of discovering the essence of real objects in nature, human society, and the human mind. Different from scientific 
knowledge, religious belief turns towards transcendental and supernatural essences and values. (Vranjes, 2018) Second, science is usually based on rational and logical thinking, while religion is irrational or, as some argue, supra-rational (i.e., not 'illogical' but rather beyond the scope of natural reason). All scientific theories are validated based on both qualitative and quantitative argumentations and/or empirical experiments. (Ambrozy - Lokajicek - Valco, 2019) On the contrary, an intuitive religious feeling and experience are essential for every religion regardless of primitive or modern ones.

In general, the Vietnamese authorities have been playing a very important role in the relationship between religion and science. In post-colonial Vietnam, state policy usually had the power to increase or reduce the gaps between religious belief and scientific knowledge for the sake of their political and economic purposes. However, despite the fact that there are some differences between East Asian non-institutional polytheistic religions and institutional monotheistic Western religions, from the viewpoint of religiosity versus secularism, the gap between religious faith and Western scientific knowledge in the last two centuries has been bigger than it was in the traditional pre-colonial Vietnam. It is the same when we talk about the relationship between rationalism and irrationalism in traditional and contemporary Vietnam. In both aspects, the gap between Western science and religion in colonial and post-colonial periods were bigger and more problematic than it was in precolonial Vietnam. Vietnamese contemporary culture is more paradoxical than it was traditionally. However, due to indigenous factors from both the perspectives of religiosity vs. secularism as well as rationalism vs. non-rationalism, it would be an exaggeration to say that between Western science and religion in Vietnam, there is only antagonism. Rather, they both operate on two different planes of existence which intersect in the one, unified human experience (rational and intuitive) with its moral implications. (Zalec - Pavlikova, 2019) However, to facilitate a productive dialogue and cooperation, "the legitimate dialogue partners," that is, science and religion, must "avoid the pitfalls of scientism as well as blind and irrational fundamentalism (both, religious and secular-ideological).” (Valco - Boehme, 2017: 95)

\section{ACKNOWLEDGMENTS}

1. This article was sponsored by a project KHCN-TB.13X13-18, Vietnam National University, Hanoi.

2. The work is performed according to the Russian Government Program of Competitive Growth of Kazan Federal University.

3. The work is performed according to the Program of Development of Financial University under the Government of the Russian Federation for 2020.

4. The publication has been supported by the 'Russian Academic Excellence Project 5

- 100' of the I M Sechenov First Moscow State Medical University (Sechenov University).

\section{Bibliographic references}

AMBROZY, M. - LOKAJICEK, M. - VALCO, M. 2019. Classical Mechanics and Contemporary Fundamental Physical Research. In: Philosophia, vol. 20, n. 2, pp. 212237. ISSN 2244-1875.

BENDA, H. 1972. The structure of Southeast Asian History: some preliminary observations. In: Continuity and Change in Southeast Asia. Collected Journal Articles of Harry Benda. Yale University Southeast Asia Studies Monograph Series No. 18. New Heaven: Yale University Publishing.

CADIERE, L. 2010. Croyances et Practiques religieuses des Vietnamiens (Van hoa, tin nguong va thuc hanh ton giao nguoi Viet), tap III, Nxb. Thuan Hoa: Hue.

CAMBRIDGE DICTIONARY. 2020. Culture. Available online: https://dictionary.cambridge.org/dictionary/english/culture) 
CHANEY, D. C. 2001. From ways of life to lifestyle: Rethinking culture as ideology and sensibility. In J. Lull (ed.), Culture in the communication age. London: Routledge, pp. $75-88$.

COHEN, H. F. 2010. How modern science came into the world. Four civilizations, one 17th-century breakthrough. 2nd ed. Amsterdam: Amsterdam University Press. ISBN 9789089642394.

COLLIER, M. J. - HEGDE, R. S. - LEE, W. - NAKAYAMA, T. K. - YEP, G. A. 2002. Dialogue on the edges: Ferment in communication and culture. In M. J. Collier (Ed.), Transforming communication about culture: Critical new directions. Thousand Oaks: Sage, pp. 219-280.

COLLIER, M. J. 2003. Understanding cultural identities in intercultural communication: A ten-step inventory. In L. A. Samovar \& R. E. Porter (eds.), Intercultural communication: A reader (10th ed.). Belmont: Wadsworth, pp. 412-429.

CORSINI, R. J. 1999. The dictionary of psychology. Philadelphia, PA: Brunner/Mazel.

DAWSON, C. 1948. Religion and culture. [Religion und Kulture. Duesseldorf: Verlag L. Schwann, 1951]. London.

ENCYCLOPAEDIA BRITANNICA. 2020. Religion. Available online: https://www.britannica.com/topic/religion

FERNGREN, G.B. (ed.). 2017. Science and Religion: a historical introduction. 2nd edition. Baltimore: Johns Hopkins University Press.

GIAU, T.V. 1973. The development of Vietnamese thoughts [Su phat trien cua tu tuong o Viet Nam]. Tap I, Nxb. Ha Noi: Khoa hoc xa hoi.

GOLDSTEIN, B. R. 2016. Copernicus and the Origin of his Heliocentric System. In: Journal for the History of Astronomy, vol. 33, n. 3, pp. 219-235. Doi: $10.1177 / 002182860203300301$.

GRANT, E. 1996. The Foundations of Modern Science in the Middle Ages: Their Religious, Institutional and Intellectual Contexts. Cambridge Studies in the History of Science. Cambridge University Press, pp. 7-17. ISBN 978-0521567626.

GRANT, E. 1997. History of Science: When Did Modern Science Begin?. In: The American Scholar, vol. 66, vol. 1, pp. 105-113. JSTOR 41212592

GRANT, E. 2007. Islam and the eastward shift of Aristotelian natural philosophy. In: A History of Natural Philosophy: From the Ancient World to the Nineteenth Century. Cambridge University Press, pp. 62-67. ISBN 978-0-521-68957-1.

HEILBRON, J.L. 2003. Preface. In: The Oxford Companion to the History of Modern Science. New York: Oxford University Press, pp. vii-X. ISBN 978-0-19-511229-0.

HIRSCHBERGER, J. 1991. Geschichte der Philosophy, Band II. Sonderausgabe. Freiburg - Basel - Wien: Herder.

HUOU, T.D. 2001. Lectures on Eastern thoughts [Cac bai giang ve tu tuong Phuong Dong]. Lai Nguyen An bien soan, Nxb. Ha Noi: Dai hoc Quoc gia Ha Noi.

KIM, T.T. 2003. A Short History of Vietnam [Viet Nam suluoc]. Da Nang: Nxb. Da Nang.

NGUYEN, L. 2010. A History of Vietnamese Buddhism [Viet Nam Phat giao su luan]. Saigon.

LENH, M.A. - TU, N. V. 2014. An approach to Hmong culture [Tiep can van hoa Hmong]. Ha Noi: Nxb. Van hoa dan toc.

LINDBERG, D. C. 1992. The Beginnings of Western Science. University of Chicago Press. ISBN 9780226482040.

LINDBERG, D. C. 2007. The beginnings of Western science: the European Scientific tradition in philosophical, religious, and institutional context. $2^{\text {nd }}$ edition. Chicago, Illinois: University of Chicago Press, pp. 1-27. ISBN 978-0-226-48205-7.

MCGINNIS, J. 2010. The Canon of Medicine. Oxford: Oxford University. 
MERRIAM-WEBSTER DICTIONARY. 2020. Culture. Available online: https://www.merriam-webster.com/dictionary/culture

MONGRAIN, K. 2017. Anxiety or Equanimity: Christoph Schönborn and Hans Urs von Balthasar on the Relationship of Science and Christian Truth. In: Theologos, vol. XIX, n. 2, pp. 34-48. ISSN 1335-5570.

PINGREE, D. 1992. Hellenophilia versus the History of Science. In: Isis, vol. 83, n. 4, pp. 554-563. Doi:10.1086/356288.

SCHOCKENHOFF, E. 2014. On the ethos of theology: A Science of faith between the Church and Secular society. In: Bogoslovni Vestnik, vol. 74, n. 1, pp.7-28.

TAM, T.T.N. 2016. The new way. Protestantism and the Hmong in Vietnam. SeattleLondon: University of Washington Press.

TAN, H.V. 1984. Some observations on history of Vietnam and Vietnamese thoughts [May suy nghi ve lich su Viet Nam va tu tuong Viet Nam]. In: Vien Triet hoc, Some theoretical issues of history of Vietnamese thoughts [Mot so van de ly luan ve lich su tu tuong Viet Nam]. Ha Noi: Academic Publishing, pp. 21-35.

TANG, L.H. 1984. History of thought, history of philosophy or history of Vietnamese philosophical thoughts? [Lich su tu tuong, lich su triet hoc hay lich su tu tuong triet hoc Viet Nam?]. In: Vien Triet hoc, Some theoretical issues of history of Vietnamese thoughts [Mot so van de ly luan ve lich su tu tuong Viet Nam]. Ha Noi: Academic Publishing, pp. 58-65.

THANG, L.S. 1997. History of Vietnamese thoughts [Lich su tu tuong Viet Nam]. Tap II. Ha Noi: Nxb. Khoa hoc xa hoi.

THU, N. T. 1984. Some issues of history of Vietnamese thoughts [May van de lich su tu tuong Viet Nam]. In: Vien Triet hoc, Some theoretical issues of history of Vietnamese thoughts [Mot so van de ly luan ve lich su tu tuong Viet Nam]. Ha Noi: Academic Publishing, pp. 36-49.

TILLICH, P. 1967. Die religioese Substanz der Kultur, Schriften zur Theologie der Kultur. In: Gesamelte Werke, bd. 9. Amsterdam: Walter de Gruyter GmbH \&Co.

VALCO, M. - BOEHME, A. 2017. Christian Faith and Science: Can Science Enhance Theology? In: European Journal of Science and Theology, vol. 13, n. 3, pp. 89-97.

VIEN, N. K. 1995. On Confucianism [Ban ve dao Nho]. Ha Noi: Nxb. Khoa hoc xa hoi.

VRANJES, N. 2018. Understanding Creation and Scientific Explanation of the Origin of Life in a Contemporary Pastoral and Catechetical Context. In: Bogoslovni vestnik, vol. 78, n. 1, pp. 91-103.

WHITEHEAD, A.N. 1960. Science and the modern World. New York: New American Library.

WEBER, M. 1988. Die Wirtschaftsethik der Weltreligionen. Konfuzianismus und Taoismus. In: Gesammelte Aufsaetze zur Religionssoziologie, Band 1. Tuebingen: Mohr Siebeck.

WOODSIDE, A. B. 1971. Vietnam and the Chinese Model. A comparative study of Nguyen and Ching civil government in the first half of the nineteenth century. Cambridge, Massachusetts: Harvard University Press.

WOODSIDE, A. B. 1988. Vietnam, 1802-1867: New challenge to old authority and Vietnam. Social change and the emergence of nationalism. In: Steinberg David J. (ed.), In Search of Southeast Asia, A modern history. Honolulu: University of Hawaii Press.

ZALEC, B. - PAVLIKOVA, M. 2019. Civic virtues and functions of religion in public life. In: European Journal of Science and Theology, vol. 15, n. 6, pp. 75-84.

Words: 11615

Characters: 76639 (42,58 standard pages) 
Assoc. prof. Quang Hung Nguyen, PhD.

Vietnam National University

College of Social Sciences and Humanities

336 Nguyen Trai, Thanh Xuan Trung, Thanh Xuan, Ha Noi,

Vietnam

nguyenquanghung50@gmail.com

Assoc. prof. Katarina Valcova, PhD.

Comenius University of Bratislava

Lutheran Theological Faculty

Bartokova 8, 81102 Bratislava

Slovak Republic

katarina.valcova@gmail.com

Prof. Venera G. Zakirova

Institute of Psychology and Education

Kazan (Volga region) Federal University

18 Kremlyovskaya Street

420008 Kazan

Russian Federation

zakirovav-2011@mail.ru

Assoc. Prof. Anna A. Larionova, $\mathrm{PhD}$

Department of Corporate Finance and Corporate Governance

Financial University under the Government of the Russian Federation

49 Leningradsky Prospekt

125993 Moscow

Russian Federation

annla@list.ru

Assoc. Prof. Natalja I. Lapidus, PhD

Department of Urgent and Outpatient Therapy

I.M. Sechenov First Moscow State Medical University (Sechenov University)

8 Trubetskaya Street

119991, Moscow

Russian Federation

nat_lap@mail.ru 